\title{
PENGEMBANGAN APLIKASI PERMAINAN EDUKASI UNTUK ANAK PRASEKOLAH MENGGUNAKAN PENDEKATAN CHILD CENTERED DESIGN
}

\author{
Rosa Delima ${ }^{1}$ \\ rosadelima@staff.ukdw.ac.id
}

\author{
Nevi Kurnia Arianti ${ }^{2}$ \\ nevikurnia_a@yahoo.com
}

\author{
Bramasti Pramudyawardani ${ }^{3}$ \\ asti.bramasti@live.com
}

\begin{abstract}
This paper discusses the process of developing an education game application using Child Centered Design (CCD) approach. This approach is chosen because the method is suitable for targeted users, preschool students range from 4 to 6 years. The processes of developing the applications consist four stages: the specification of the use of the application, the specification of application requirements, design and application development, and evaluations. Children as the main respondent in this research play an important role in three stages: determining the specifications of the use of the application, the specification of application requirements, and evaluation of applications. Seventy three children are participated in this research. Observation and discussion among the children are used to collect data and information. An observation was conducted to determine the activity and behavior of children, while the discussion method conducted to gather information and opinions of children. In particular, this research involves the interviewer and evaluators who understand the behavior of children and able to communicate with children.
\end{abstract}

Keywords : HCI, CCI, Child Centered Design, Educational Game, Children Computer Game.

\section{Pendahuluan}

\subsection{Latar Belakang}

Desain antarmuka merupakan bagian yang sangat penting dalam membangun sebuah perangkat lunak. Melalui antarmuka yang baik dan sesuai, pengguna dapat memahami dan menggunakan sistem dengan mudah, efektif, dan merasakan kenyamanan dalam berinteraksi dengan sistem. Salah satu pendekatan yang banyak digunakan dalam membangun antarmuka sistem adalah pendekatan yang berpusat pada pengguna (User Centered Design). User Centered Design (UCD) merupakan sebuah pendekatan untuk membangun sebuah antarmuka yang difokuskan kepada orang/pengguna yang akan mengoperasikan sistem. Para Pengguna akan dilibatkan secara langsung dalam proses perencanaan, perancangan dan pengembangan sistem. Pengguna yang dilibatkan dalam pendekatan UCD umumnya adalah orang dewasa yang telah memiliki kemampuan komunikasi yang baik.

Berbeda dengan orang dewasa, anak-anak khususnya anak pra-sekolah belum memiliki kemampuan komunikasi yang baik dan kendala kesenjangan pengetahuan antara perancang dan anak juga menjadi kendala utama dalam membangun sebuah antarmuka yang sesuai untuk anak. Oleh karena itu untuk membangun sebuah aplikasi untuk anak dibutuhkan sebuah pendekatan khusus yang memahami karakteristik dari anak. Salah satu pendekatan yang dapat digunakan adalah Pendekat Child Centered Design (CCD).

Child Centered Design (CCD) merupakan pendekatan UCD yang berfokus pada pengguna anak-anak. Dalam pendekatan ini terdapat beberapa teknik yang berbeda dengan pendekatan UCD antara lain cara berkomunikasi dan berinteraksi dengan pengguna dan

\footnotetext{
${ }^{1}$ Program Studi Teknik Informatika Fakultas Teknologi Informasi UKDW Yogyakarta

${ }^{2}$ Program Studi Teknik Informatika Fakultas Teknologi Informasi UKDW Yogyakarta

${ }^{3}$ Program Studi Teknik Informatika Fakultas Teknologi Informasi UKDW Yogyakarta
} 
proses evaluasi yang dilakukan terhadap sistem. Oleh karena itu pendekatan CCD sangat cocok digunakan untuk pengembangan aplikasi dengan pengguna utama anak.

\subsection{Rumusan Masalah}

Rumusan masalah yang dibahas dalam paper ini adalah penerapan metode Child Centered Design untuk dapat lebih meningkatkan peran serta anak dalam pengembangan sebuah aplikasi permainan edukasi.

\subsection{Tujuan Penelitian}

Tujuan penelitian adalah untuk mengetahui tahapan atau proses yang harus dilakukan dalam pendekatan child centered design agar anak dapat menjadi responden utama dalam pengembangan sebuah aplikasi.

\section{Tinjauan Pustaka.}

\subsection{Human Computer Interaction}

User-centered Design (UCD) merupakan sebuah pendekatan yang mengkombinasikan beberapa langkah, metode, dan beberapa tool perancangan sistem untuk mendukung seorang pengembang sistem di dalam membuat perancangan yang sesuai dengan karakteristik pengguna sistem (Ruterberg, 2003). Dalam pengembangan sistem menggunakan pendekatan UCD terdiri dari beberapa aktivitas utama yaitu : menentukan scope dari sistem, melakukan analysis, perancangan, validasi dan implementasi sistem. Proses didalam pendekatan ini bersifat iteratif dan proses akan berulang sampai produk akhir berhasil dibangun. Gambar 1 . merupakan gambar aktifitas yang dilakukan dalam pendekatan UCD (Wallach \& Schols, 2012)

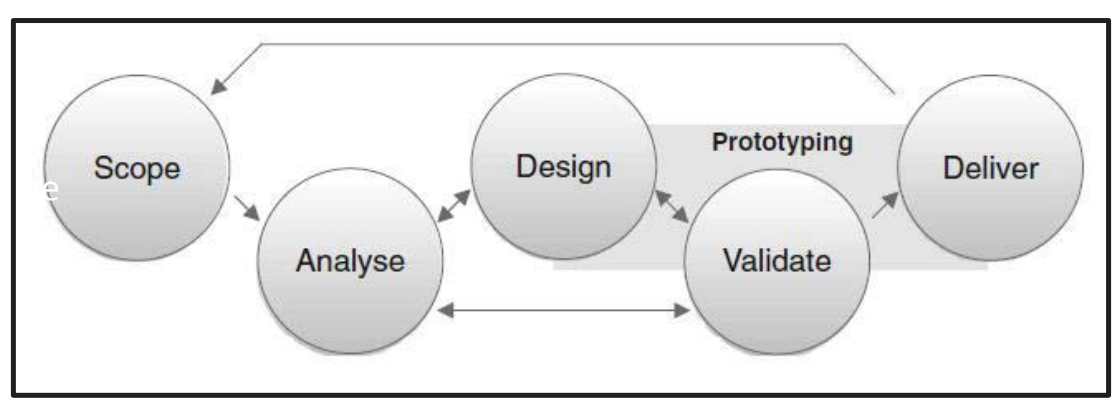

Gambar 1. User-centered Design Activities (Wallach \& Schols, 2012)

\subsection{Child Computer Interaction}

Dengan berkembangnya kebutuhkan untuk menciptakan teknologi interaktif bagi anak, memunculkan kebutuhan akan sebuah teknik untuk melakukan perancangan untuk teknologi tersebut. Unsur penting dalam perancangan ini adalah bagaimana melibatkan anak dalam proses pengembangan teknologi. Child Computer Interaction (CCI) merupakan bidang yang berkembang dari Human Computer Interaction (HCI). Tidak seperti HCI yang telah berkembang dengan luas dan banyak digunakan dan diteliti, CCI masih merupakan bidang ilmu yang relatif baru dan belum banyak diteliti. Menurut Markopoulos (2008), penyebab utama perkembangan CCI berjalan lambat adalah karena CCI merupakan bidang yang menggabungkan beberapa bidang ilmu yang berbeda, seperti sosiologi, pendidikan, teknologi pendidikan, seni dan desain, psikologi dan komputer. CCI muncul dan berkembang didasarkan pada perbedaan karakteristik antara anak dan orang dewasa. karakteristik utama pengguna anak adalah mereka memiliki kemampuan komunikasi yang belum matang, kemampuan kognitif yang masih terbatas, dan adanya perbedaan yang cukup besar antara pengetahuan yang dimiliki anak dan yang dimiliki oleh perancang sistem dewasa. HCI sering digunakan untuk merancang dan mengevaluasi sistem dengan target pengguna orang dewasa (Pardo dkk, 2008). Oleh karena itu untuk pengguna sistem kategori anak dibutuhkan pendekatan khusus yang dikenal dengan CCI. Fokus utama CCI adalah mengetahui kebutuhan anak dan dampak produk terhadap perkembangan anak. Gambar 2. merupakan skema yang 
menggambarkan hubungan antara Human Computer Interaction dan Child Computer Interaction.

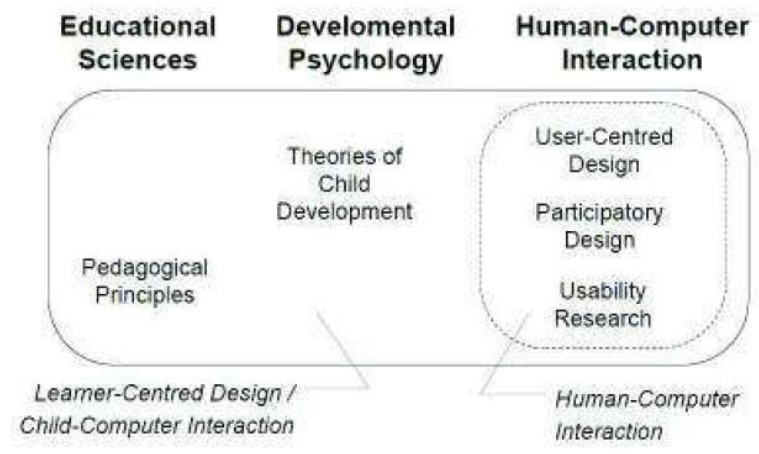

Gambar 2. Human Computer Interaction dan Child Computer Interaction (Nousiainen, 2008).

\subsection{Child Centered Design.}

Satu pendekatan yang digunakan dalam Child Computer Interaction adalah Childcentered Design (CCD). CCD merupakan sebuah pendekatan pengembangan antarmuka untuk sistem yang pengguna akhirnya adalah anak-anak. CCD merupakan pendekatan yang mengadopsi beberapa tahapan dalam UCD, namun perbedaan utama kedua pendekatan ini adalah pengguna akhir dari sistem. Dalam pendekatan UCD, penggunaan akhir sistem merupakan orang dewasa, sedangkan CCD berfokus pada pengguna akhir anak-anak (Idler, 2013). Meskipun fokus pengguna akhir dari sistem adalah anak, namun dalam CCD peran orang tua dan guru sebagai mediator tetap diperhitungkan dan menjadi bagian dalam proses perancangan sistem (Pardo dkk, 2008).

Dalam pendekatan CCD terdapat 4 aktifitas utama yaitu specify the context of use, specific product requirement, product design solution, and evaluate design. Sama seperti UCD, semua aktifitas akan berulang sampai produk akhir berhasil dikembangkan. Hubungan antara keempat aktifitas yang ada dapat dilihat pada gambar 3 .

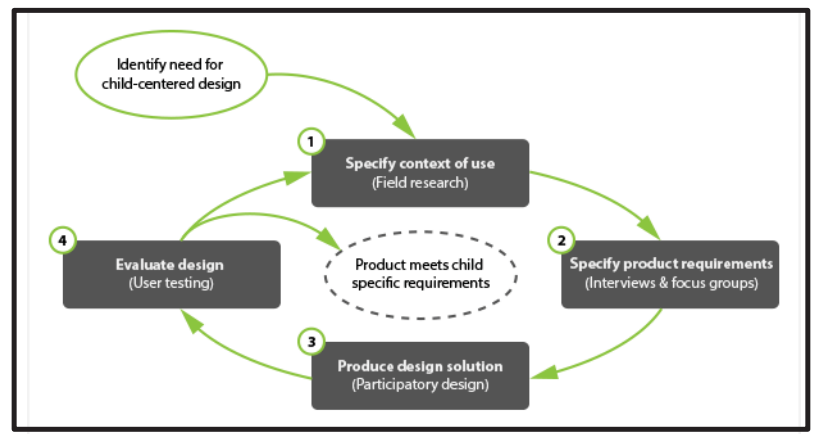

Gambar 3. Empat aktifitas utama dalam pendekatan Child-centred Design (Idler, 2013)

Tahap awal yang harus dilakukan dalam CCD adalah menentukan spesifikasi dari konteks penggunaan sistem. Dalam tahap ini diidentifikasi siapa yang akan menggunakan produk, apa fungsi produk bagi pengguna, dan kondisi apa saja yang mempengaruhi mereka untuk menggunakan sistem. Tahapan ini dapat dilakukan melalui wawancara dengan orang tua, guru, dan orang dewasa lainnya yang dapat memberikan informasi mengenai perilaku anak. Pada anak dapat dilakukan observasi mengenai perilaku dan aktifitas yang dilakukan anak terkait sistem yang akan dibangun (Idler, 2013).

Berdasarkan spesifikasi konteks penggunaan sistem yang telah ditentukan maka dapat dilakukan penggalian informasi lebih lanjut untuk dapat mendefinisikan spesifikasi kebutuhan. Dalam tahapan spesifikasi kebutuhan penting untuk mengetahui tujuan dari sistem dan tujuan dari pengguna sistem sehingga kedua tujuan ini dapat terpenuhi. Tahapan berikutnya adalah proses perancangan sistem. Proses ini dilakukan dengan menggunakan 
pendekatan partisiparori atau bottom-up. Perancangan dilakukan berdasarkan dari kebutuhan, masukan dan karekteristik pengguna. Setelah sistem dirancang dan dibangun prototipe dari sistem akan dilakukan evaluasi terhadap desain. Proses evaluasi dilakukan melalui uji usabilitas. Khusus untuk CCD uji usabilitas dilakukan sesuai dengan standar uji sistem untuk anak (Idler, 2013).

\subsection{Permainan Edukasi.}

Kata game berasal dari Bahasa Inggris yang berarti permainan. Permainan adalah sesuatu yang dapat dimainkan dengan aturan tertentu sehingga ada menang dan ada kalah. Permainan adalah salah satu jenis kegiatan bermain dimana pemainnya berusaha meraih tujuan dari permainan tersebut dengan melakukan aksi sesuai dengan aturan pada permainan (Adams \& Rollings, 2007). Game edukasi merupakan permainan yang dirancang atau dibuat untuk merangsang daya pikir termasuk meningkatkan konsentrasi dan memecahkan masalah (Handriyantini, 2009). Game edukasi menjadi salah satu jenis media yang digunakan untuk memberikan pengajaran, menambah pengetahuan penggunanya melalui suatu media unik dan menarik. Target pengguna untuk aplikasi ini biasanya anak-anak. Oleh karena itu tantangan dan kesesuaian antara materi dengan kemampuan anak menjadi faktor yang sangat penting dalam merancangan sebuah permainan edukasi.

Menurut Hurd \& Jenuings (2009), perancangan game edukasi yang baik harus memenuhi beberapa kriteria berikut ini :
a. Nilai Keseluruhan (Overall Value)
b. Dapat Digunakan (Usability)
c. Keakuratan (Accuracy)
d. Kesesuaian (Appropriateness)
e. Relevan (Relevance)
f. Objektifitas (Objectives)
g. Umpan Balik (Feedback)

\section{Metode Penelitian.}

Penerapan Metode Child Centered Design dalam pengembangan aplikasi dilakukan melalui empat tahapan utama yaitu spesifikasi penggunaan aplikasi, spesifikasi kebutuhan aplikasi, perancangan dan pengembangan aplikasi, dan evaluasi. Skema Pengembangan aplikasi dapat dilihat pada gambar 4 .

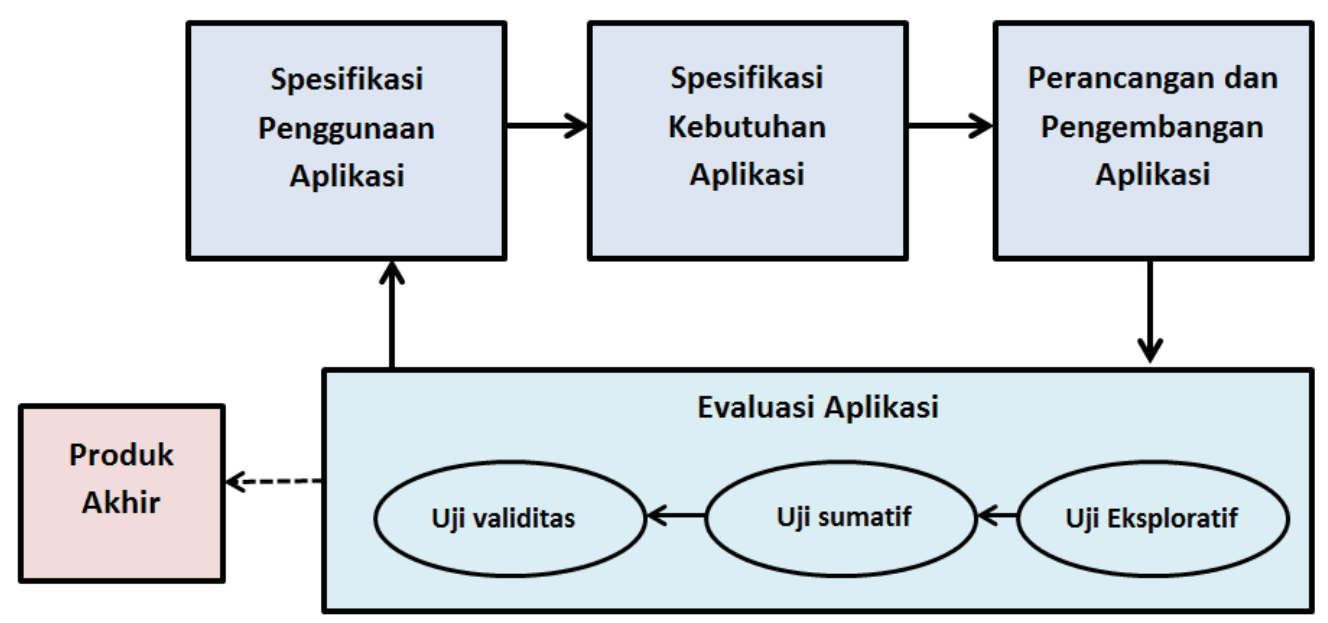

Gambar 4. Skema Pengembangan Aplikasi

\subsection{Spesifikasi Penggunaan Aplikasi.}

Tahapan awal dalam pengembangan sistem adalah melakukan spesifikasi penggunaan aplikasi. Sebelum dapat melakukan pengumpulan data mengenai spesifikasi penggunaan aplikasi, tim peneliti terlebih dahulu menentukan target responden untuk penelitian. Kemudian dilanjutkan dengan tahap perkenalan sebagai bentuk komunikasi awal dengan 
anak. Untuk mendapatkan data yang lebih lengkap, penelitian ini juga melibatkan orang tua, guru dan ahli tumbuh kembang anak dalam proses penentuan spesifikasi penggunaan dan kebutuhan aplikasi. Teknik pendekatan pengumpulan data pada tahap ini meliputi observasi, wawancara, dan kuistioner. Observasi dilakukan terhadap anak. Observasi dilakukan selama anak berada disekolah. Observasi yang dilakukan meliputi urutan aktifitas yang dilakukan anak di sekolah, lamanya waktu belajar dan konsentrasi anak, aktifitas bermain yang lakukan dan permainan / aktifitas / benda yang dapat menarik perhatian anak. Selain terhadap anak observasi juga dilakukan pada guru di kelompok bermain dan taman kanak-kanak. Unsur yang diobservasi meliputi cara guru mengajar, aktifitas yang dilakukan guru untuk menarik perhatian anak, dan cara guru memperkenalkan atau mengajarkan sesuatu kepada anak. Metode lain yang dilakukan untuk pengumpulan data adalah wawancara. Wawancara dilakukan terhadap ahli tumbuh kembang anak dan guru. Wawancara dilakukan untuk informasi dan pengetahuian terkait pandangan responden terhadap aplikasi pembelajaran, teknik atau cara untuk menarik perhatian anak beserta unsur-unsur yang dapat membuat anak merasa senang berinteraksi dengan sesuatu (seperti permainan dan pelajaran), dan interval waktu konsentrasi yang dimiliki olah anak. Pengumpulan data melalui kuistioner hanya dilakukan dengan orang tua/ wali anak. Data pada kuistioner meliputi identitas orang tua dan anak dan interaksi anak dengan perangkat teknologi. Daftar responden yang dilibatkan pada tahap ini dapat dilihat pada tabel 1 .

Berdasarkan analisis dan pengolahan data, pada tahapan ini dilakukan definisi target utama pengguna aplikasi yaitu anak prasekolah yang berusia 4 sampai 6 tahun. Bentuk aplikasi yang dikembangkan merupakan aplikasi permainan edukasi, yang memiliki unsur "fun" atau menyenangkan dan unsur pendidikan. Unsur menyenangkan akan dipenuhi melalui pemilihan karakter, warna dan obyek yang digemari oleh anak-anak. Sementara unsur pendidikan yang dimasukan kedalam aplikasi meliputi pengetahuan dasar seperti mengenai warna, pola/obyek dan aktifitas berhitung dan mewarnai. Melalui pendefinisian unsur-unsur ini diharapkan nantinya anak tertarik untuk menggunakan aplikasi.

Tabel 1.

Daftar Responden pada Tahap Spesifikasi Penggunaan Aplikasi

\begin{tabular}{|l|c|l|}
\hline \multicolumn{1}{|c|}{ Responden } & Jumlah Responden & \multicolumn{1}{|c|}{ Metode yang digunakan } \\
\hline Anak & 25 & Observasi \\
\hline Pakar/ahli tumbuh kembang anak & 2 & Wawancara \\
\hline Guru Taman Kanak-kanak. & 2 & Wawancara dan Observasi \\
\hline Orang Tua/wali & 52 & Kuistioner \\
\hline Total Responden & 81 & \\
\hline
\end{tabular}

\subsection{Spesifikasi Kebutuhan Aplikasi.}

Tahap berikutnya yang dilakukan dalam pengembangan aplikasi adalah menentukan spesifikasi kebutuhan sistem. Dalam tahap ini dirumuskan definisi tujuan penggunaan sistem dan definisi karakterisitik utama pengguna. Sama dengan tahapan spesifikasi penggunaan sistem, tahapan ini juga dilakukan melalui metode wawancara, observasi dan kuistioner. Responden yang dilibatkan sama dengan responden pada tabel 1 . Proses pengumpulan data dilakukan dengan bantuan 3 orang pewawancara yang merupakan sarjana psikologi yang paham mengenai karakteristik dan perilaku anak.

Tahapan ini menghasilkan rumusan tujuan penggunaan aplikasi dan karakteristik utama pengguna. Rumusan tujuan penggunaan aplikasi dirumuskan sebagai berikut : 1) aplikasi permainan ditujukan untuk anak usia 4 sampai 6 tahun, 2) aplikasi dibuat menarik 
dan menyenangkan, 3) aplikasi dapat dipergunakan untuk mengembangkan berbagai kemampuan anak. Kemampuan yang dikembangkan meliputi kemampuan motorik halus penggunaan perangkat mouse dan keyboard komputer, kemampuan anak mencocokan warna, kemampuan mengurutkan angka atau huruf, kemampuan matematika sederhana, kemampuan mengenali obyek dan kemampuan melengkapi huruf sebuah kata.

Karakteristik pengguna aplikasi yang merupakan anak usia 4 samapi 6 tahun dirumuskan menjadi 6 kategori dengan 24 kriteria (Delima dkk, 2015). Keenam kategori tersebut meliputi : 1) penggunaan tombol navigasi dan instruksi, 2) kemampuan kognitif anak, 3) kemampuan psikomotorik anak, 4) kemampuan mengingat dan konsentrasi anak, 5) ketertarikan anak terhadap sebuah aplikasi dan 6) cara anak memberikan penilaian. Tabel 2 merupakan daftar karakteristik pengguna aplikasi.

Tabel 2.

Karakteristik Pengguna Aplikasi.

(Delima dkk, 2015)

\begin{tabular}{|c|c|}
\hline Standar & Kriteria \\
\hline $\begin{array}{c}\text { Standar 1: } \\
\text { Tombol Navigasi } \\
\text { dan Instruksi }\end{array}$ & $\begin{array}{l}\text { 1. Anak prasekolah membutuhkan tombol navigasi dengan diameter } \\
\text { empat kali lebih besar agar mereka dapat memilih tombol tersebut } \\
\text { dengan menggunakan mouse. } \\
\text { 2. Antarmuka dengan navigasi berbentuk hirarki harus dihindari. } \\
\text { 3. Teknologi harus menyedia fasilitas bantuan. } \\
\text { 4. Instruksi yang mudah dipahami oleh anak prasekolah adalah instruksi } \\
\text { dengan bahasa sederhana dan disertai contoh visual. }\end{array}$ \\
\hline $\begin{array}{c}\text { Standar 2 : } \\
\text { Kemampuan } \\
\text { Kognitif Anak }\end{array}$ & $\begin{array}{l}\text { 1. Anak prasekolah dapat mengidentifikasi bentuk sederhana, mengenal } \\
\text { warna, menghitung sampai 10, dan mengenal beberapa huruf. } \\
\text { 2. Perbedaan kemampuan anak harus dipertimbangkan dalam tahap uji } \\
\text { usabilitas sistem. } \\
\text { 3. Teknologi harus mengembangkan banyak kecerdasan pada anak } \\
\text { melalui berbagai cara. } \\
\text { 4. Anak prasekolah mengerti relasi one-to-one, misalnya mereka } \\
\text { mengerti peta sederhana, icon, dan representasi visual lainnya. } \\
\text { 5. Anak prasekolah mampu mengklasifikasikan objek menurut jenis atau } \\
\text { mengurutkan mereka berdasarkan ukurannya. } \\
\text { 6. Anak prasekolah paham dengan konsep "hari ini" dan urutan } \\
\text { beberapa kejadian. } \\
\text { 7. Beberapa permainan komputer mendukung perkembangan } \\
\text { kemampuan anak, seperti permainan mewarnai, permainan mengenal } \\
\text { angka dan huruf, permainan berhitung, dan permainan melengkapi } \\
\text { dan menyusun kata. }\end{array}$ \\
\hline $\begin{array}{c}\text { Standar } 3 \text { : } \\
\text { Kemampuan } \\
\text { Psikomotorik } \\
\text { Anak }\end{array}$ & $\begin{array}{l}\text { 1. Anak prasekolah memiliki kemampuan motorik yang baik dan } \\
\text { mampu membedakan obyek visual yang dapat digunakan untuk } \\
\text { mengendalikan peralatan komputer seperti mouse dan keyboard, } \\
\text { namun mereka hanya dapat fokus pada satu tangan dan satu aspek } \\
\text { pada waktu yang bersamaan. Oleh karena itu permainan untuk anak } \\
\text { prasekolah harus dibuat sesederhana mungkin. } \\
\text { 2. Permainan komputer dengan menggunakan mouse dapat melatih } \\
\text { motorik halus pada anak dan jika diberikan beberapa kali pelatihan, } \\
\text { anak usia prasekolah dapat mengoperasikan mouse dan keyboad } \\
\text { komputer secara baik. Mereka sudah dapat memilih objek, melakukan } \\
\text { klik, serta drag-and-drop. }\end{array}$ \\
\hline
\end{tabular}




\begin{tabular}{|c|c|}
\hline Standar & Kriteria \\
\hline $\begin{array}{c}\text { Standar 4 : } \\
\text { Kemampuan } \\
\text { Mengingat dan } \\
\text { Konsentrasi } \\
\text { Anak }\end{array}$ & $\begin{array}{l}\text { 1. Kemampuan mengingat anak lebih sedikit dari orang yang lebih } \\
\text { dewasa. } \\
\text { 2. Karena anak menyimpan informasi dalam bentuk verbal, maka } \\
\text { sebaiknya teknologi harus mengadaptasi kemampuan tersebut agar } \\
\text { anak dapat belajar. } \\
\text { 3. Anak prasekolah dapat bermain sendiri pada periode waktu tertentu } \\
\text { (sekitar } 20 \text { menit) dan mereka juga dapat bermain dalam kelompok. } \\
\text { 4. Anak prasekolah dapat menikmati dan mengingat lagu kesukaan } \\
\text { mereka. } \\
\text { 5. Kemampuan konsentrasi anak prasekolah rata-rata antara } 10 \text { sampai } \\
15 \text { menit. }\end{array}$ \\
\hline $\begin{array}{c}\text { Standar 5 : } \\
\text { Kriteria } \\
\text { kertertarikan } \\
\text { Anak Terhadap } \\
\text { Sebuah Aplikasi }\end{array}$ & $\begin{array}{l}\text { 1. Anak laki-laki dan perempuan berinteraksi dengan aplikasi } \\
\text { multimedia secara berbeda: anak perempuan senang dibantu dan } \\
\text { tertarik dengan tampilan visual, sementara anak laki-laki menilai } \\
\text { kontrol, kecepatan dan navigasi. } \\
\text { 2. Karakter utama permainan yang menarik dan disukai anak adalah } \\
\text { karakter yang lucu dan ceria. } \\
\text { 3. Anak menyukai warna-warna yang mencolok. } \\
\text { 4. Tantangan dalam permainan sangat penting untuk membangkitkan } \\
\text { keingintahuan anak dan meningkatkan ketertarikan anak terhadap } \\
\text { permainan. } \\
\text { 5. Kata-kata pujian dan motivasi sangat penting untuk memotivasi anak. } \\
\text { 6. Bentuk aktifitas dalam permainan harus beragam untuk menghindari } \\
\text { kebosanan pada anak. } \\
\text { 7. Sebagian anak menyukai musik dan suara dalam permainan. }\end{array}$ \\
\hline $\begin{array}{c}\text { Standar } 6 \text { : Cara } \\
\text { Anak Memberi } \\
\text { Penilaian }\end{array}$ & $\begin{array}{l}\text { Anak lebih sering membuat penilaian secara kualitatif dari pada } \\
\text { kuantitatif }\end{array}$ \\
\hline
\end{tabular}

\subsection{Perancangan dan Pengembangan Aplikasi.}

Perancangan sistem dilakukan berdasarkan spesifikasi penggunaan aplikasi dan spesifikasi kebutuhkan aplikasi. Dalam pengembangan aplikasi permainan terdapat beberapa komponen yang dirancang yaitu rancangan story line, rancangan game play, rancangan karakter, dan rancangan grafis permainan. Story line permainan dirancang dengan mengadopsi cerita bagian dari cerita anak "Jack and the Beanstalk". Bagian yang diambil dari cerita ini adalah bagian dimana Jack/ tokoh utama cerita memanjat pohon kacang. Permainan diawali dengan seorang pemuda bernama Jack yang ingin menyelamatkan seorang putri yang ditangkap oleh raksasa dan dibawa ke istana awan. Tugas utama Jack adalah menyelamatkan sang putri.

Game play permainan berkaitan dengan aktifitas yang dilakukan Jack untuk dapat menyelamatkan sang Putri. Untuk melaksanakan tugas tersebut, Jack harus memanjat pohon kacang dengan cara melompat dari satu daun ke daun yang lain dan mengambil beberapa kacang untuk dapat mencapai pintu-pintu istana. Pada setiap pintu terdapat tantangan yang harus diselesaikan. Unsur edukasi dimasukan ke dalam aplikasi melalui aktifitas tantangan yang harus diselesaikan oleh pengguna. Materi tantangan meliputi aktifitas mewarnai, mengurutkan angka atau huruf, matematika sederhana dan melengkapi huruf. Sebagai hadiah jika anak dapat menyelesaikan tantangan maka merka akan mendapatkan satu jenis buah. Anak harus mengumpulkan delapan jenis buah-buah yang berarti ada delapan pintu yang harus dilalui. Buah-buahan yang berhasil dikumpulkan akan diberikan kepada raksasa agar raksasa mau melepaskan putri raja. Untuk navigasi input pada permainan menggunakan 
mouse dan keyboard komputer. Keyboard digunakan untuk melompati dan mengumpulkan kacang, sementara mouse digunakan untuk menyelesaikan tantangan.

Rancangan karakter permainan disesuaikan dengan karakter yang disukai anak (karakter yang lucu dan menarik) dan story line permainan. Karekter utama permainan diberi nama Jack. Visualisasi karakter Jack dan beberapa objek merupakan modifikasi dari gambar pada cerita Jack and the Beanstalk di http://www.1plus1plus1equals1.com/. Sementara itu rancangan grafis permainan didasarkan pada beberapa karakteristik utama permainan yang telah didefinisikan sebelumnya. Rancangan grafis meliputi : 1) tombol-tombol navigasi dibuat berukuran besar dan menggunakan simbol yang umum digunakan pada beberapa permainan, 2) bahasa yang digunakan adalah Bahasa Indonesia, 3) penyampaian instruksi dilakukan secara lisan (menggunakan audio) dan tulisan, 4) warna yang digunakan adalah warna-warna yang terang dan mencolok, 5)o bjek yang ditampilkan merupakan objek yang dikenal anak, seperti gambar kacang, topi, buku, hewan, dan buah-buahan. Aplikasi juga dilengkapi dengan audio. Beberapa audio dan musik diunduh dari www.playonloop.com dan DrPetter's Sfxr (http://www.drpetter.se/project_sfxr.html). Contoh beberapa tampilan grafis permainan dapat dilihat di gambar 5 .
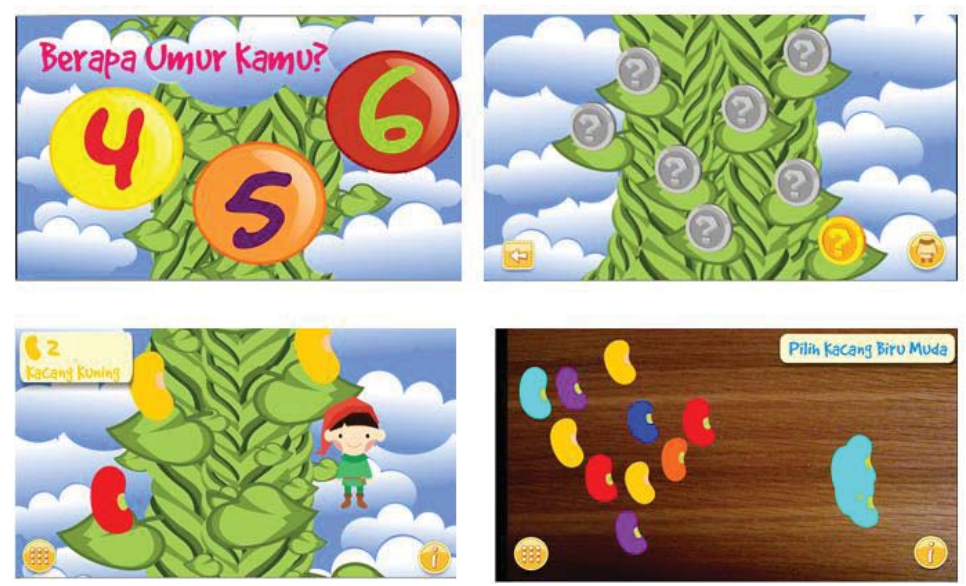

Gambar 5. Contoh Tampilan Grafis Permainan

\subsection{Evaluasi Aplikasi}

Evaluasi terhadap aplikasi dilakukan melalui 3 tahapan yaitu uji eksploratif, uji sumatif, dan uji validatif. Tahapan pengujian ini dilakukan didasarkan pada tahapan pengujian usabilitas aplikasi menurut Rubin dan Chisnell (2008). Gambar 6 merupakan gambar tahapan evaluasi aplikasi yang dikembangkan.

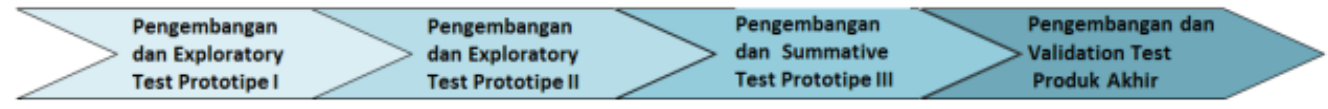

Gambar 6. Tahapan Evaluasi terhadap Aplikasi Permainan Edukasi

Pengujian aplikasi langsung dilakukan terhadap anak usia 4 sampai 6 tahun. Proses pengujian dilakukan dengan mengamati cara anak langsung memainkan aplikasi dan dilanjutkan dengan proses diskusi. Dalam pengujian tahp I dan II, setiap anak didampingi oleh sorang evaluator yang mencatat perilaku, kemampuan anak dalam bermain dan pendapat mereka mengenai aplikasi. Dalam pengujian pertama dan kedua (uji eksplorasi), setelah anak memainkan aplikasi, evaluator melakukan diskusi langsung dengan anak untuk mengetahui pendapat mereka terkait 7 fitur utama dalam aplikasi yaitu 1) karakter Jack, 2) instruksi pada permainan, 3) musik latar, 4) tantangan mewarnai gambar, 5) tantangan mengurutkan angka, 6) tantangan mengurutkan huruf, dan 7) hadiah/reward berupa buah-buahan. Anak dimintai pendapat apakah mereka menyukai atau tidak menyukai atau menganggap biasa saja ketujuh fitur tersebut. Anak juga dimintai pendapat mengenai alasan mereka menyukai atau tidak menyukai fitur yang dikembangkan. Selain berdiskusi mengenai ketujuh fitur yang ada, evaluator juga berdiskusi dengan anak mengenai obyek apa saja yang menarik bagi mereka 
beserta saran dan kritik anak terhadap aplikasi. Kedua uji eksploratif yang dilakukan menghasil sejumlah masukan dari anak untuk pengembangan aplikasi.

Evaluasi ketiga disebut uji sumatif. Evaluasi dilakukan terhadap prototipe aplikasi yang telah dikembangkan sesuai saran masukan anak pada uji eksploratif. Pengujian ini dilakukan untuk mengetahui tingkat usabilitas aplikasi. Ada empat parameter utama yang diukur yaitu learnability (kemampuan pembelajaran), throughput (tolak ukur keluaran), flexibility (keluwesan) dan satisfaction (kepuasan). Evaluasi melibatkan sepuluh orang anak berusia antara 4 sampai 6 tahun. Pengujian dilakukan dengan mengamati dan menilai anak dalam menyelesaian sekumpulan tugas sesuai dengan skenario evaluasi. Pengujian dilakukan sebanyak dua kali. Jarak antar pengujian adalah 2 minggu. Secara keseluruhan hasil dari uji usabilitas pada summative test ini adalah baik dengan karakteristik kemampuan pembelajaran anak yang cukup baik, throughput sistem yang sesuai dengan kemampuan konsentrasi pada anak, materi sudah sesuai dengan kemampuan anak, dan tingkat kepuasan anak terhadap aplikasi yang baik. Pengujian ini juga merumuskan beberapa saran untuk pengembangan aplikasi.

Berdasarkan saran pengembangan pada uji sumatif dikembangkan prototipe keempat yang merupakan produk akhir sistem. Pengujian validitas atau verifikasi dilakukan terhadap produk akhir aplikasi. Sebelum uji validitas dilakukan, terlebih dahulu dirumuskan standar aplikasi permainan edukasi untuk anak yang berusia 4 sampai 6 tahun. Selanjutnya dilakukan dua tahap uji validasi yaitu pengujian usabilitas sistem dan pengujian aplikasi berdasarkan standar yang telah dirumuskan. Uji usabilitas dalam validation test dilakukan berdasarkan 6 komponen usabiltas yaitu usefulness, efficiency, effectiveness, learnability, satisfaction, dan flexibility. Pengujian dilakukan terhadap 14 anak melalui 3 kali uji coba perangkat lunak. Jarak waktu setiap percobaan adalah 4 hari. Pengujian dilakukan dengan cara observasi dan wawancara langsung antara anak dan evaluator. Setelah uji usabilitas, pengujian dilanjutkan dengan uji validitas aplikasi yang didasarkan pada lima standar yang telah dirumuskan. Kelima standar tersebut adalah standar untuk tombol navigasi dan instruksi, standar kemampuan kognitif pengguna, standar kemampuan psikomotorik pengguna, standar kemampuan mengingat dan konsentarasi anak, dan standar kriteria ketertarikan anak terhadap sebuah aplikasi (tabel 2). Secara keseluruhan hasil uji usabilitas dan validitas aplikasi menunjukan bahwa aplikasi telah memenuhi semua unsur usabilitas dan standar aplikasi permainan edukasi untuk anak usia 4 sampai 6 tahun berdasarkan standar yang telah ditentukan.

Total keseluruhan responden yang dilibatkan dalam evaluasi sistem berjumlah 48 anak prasekolah yang berusia 4 sampai 6 tahun. Keseluruhan responen peroleh dari 3 sekolah yang merupakan kelompok bermain (KB) dan taman kanak-kanak (TK). Tabel 3. Merupakan daftar responden yang dilibatkan dalam evaluasi sistem.

Tabel 3.

Responden dalam Evaluasi Sistem

\begin{tabular}{|l|l|l|c|}
\hline \multicolumn{1}{|c|}{ Evaluasi } & Jumlah Responden & Jumlah Uji & Metode Evaluasi \\
\hline Uji Eksploratif 1 & 12 & 1 & \multirow{2}{*}{$\begin{array}{c}\text { Observasi dan } \\
\text { Wawancara }\end{array}$} \\
\hline Uji Eksploratif 2 & 12 & 1 & \\
\hline Uji Sumatif & 10 & 2 & \\
\hline Uji Validasi & 14 & 3 & \\
\hline
\end{tabular}

\section{Kesimpulan dan Saran}

\subsection{Kesimpulan}

Kesimpulan yang dapat dirumuskan pada penelitian ini adalah :

a) Pada penelitian ini berhasil dikembangkan sebuah aplikasi permainan edukasi yang didasarkan pada karakteristik anak usia 4 sampai 6 tahun. 
b) Dalam penelitian ini anak merupakan sumber data dan informasi utama dalam proses penentuan penggunaan aplikasi, penentuan spesifikasi sistem, dan evaluasi sistem.

c) Proses pengambilan data dari anak dilakukan melalui tahapan perkenalan awal, observasi aktifitas dan perilaku anak, dan diskusi langsung dengan anak.

d) Dalam pengembangan aplikasi untuk anak peran pewawancara atau evaluator sangat penting karena mereka menjadi penghubung antara anak dan pengembang sistem. Penelitian ini melibatkan pewawancara atau evaluator yang merupakan sarjana psikologi yang memahami teknik komunikasi dan perilaku anak.

e) Pendekatan Child-centered Design diterapkan dalam 4 tahapan utama pengembangan sistem meliputi spesifikasi penggunaan aplikasi, spesifikasi kebutuhan aplikasi, perancangan dan pengembangan aplikasi, dan evaluasi aplikasi.

f) Penerapan pendekatan Child-centered Design pada pengembangan aplikasi ini melibatkan 73 anak yang berusia 4 sampai 6 tahun.

g) Evaluasi terhadap standar aplikasi permainan edukasi anak prasekolah dilakukan berdasarkan 6 standar utama yang telah dirumuskan sebelumnya, yaitu standar untuk tombol navigasi dan instruksi, standar kemampuan kognitif pengguna, standar kemampuan psikomotorik pengguna, standar kemampuan mengingat dan konsentarasi anak, dan standar kriteria ketertarikan anak terhadap sebuah aplikasi, dan standar anak dalam memberikan penilaian.

h) Hasil evaluasi sistem menunjukan bahwa aplikasi memiliki usabilitas yang baik dan telah memenuhi semua standar aplikasi permainan edukasi untuk anak usia 4 sampai 6 tahun.

i) Proses evaluasi pada anak prasekolah merupakan sebuah aktifitas yang sulit dan memerlukan banyak waktu oleh karena itu setiap tahapan evaluasi harus disusun secara sistematis dan evaluator juga harus memiliki kemampuan adaptasi terhadap anak.

j) Proses ujicoba aplikasi sebaiknya hanya sekali per-satuan waktu untuk menghindari rasa bosan pada anak.

\subsection{Saran}

Berikut saran yang dapat disampaikan dari hasil penelitian yang telah dilaksanakan :

a) Perlu dibuat sebuah standar baku untuk aplikasi permainan edukasi untuk anak usia prasekolah.

b) Perlu dirumuskan standar pengukuran unsur "fun" dalam sebuah aplikasi permainan untuk anak prasekolah.

c) Untuk pengembangan aplikasi dapat dibangun navigasi sistem yang lebih baik untuk meminimalisasi peran evaluator dalam proses evaluasi sistem.

d) Perlu dilakukan penelitian terkait kebutuhan dan fitur aplikasi permainan yang sesuai dan disukai oleh anak di Indonesia.

\section{Ucapan Terima Kasih}

Ucapan terima kasih kami sampaikan kepada pihak-pihak yang telah mendukung terlaksananya penelitian ini antara lain:

1. Lembaga Penelitian dan Pengabdian Masyarakat (LPPM) dan Fakultas Teknologi Informasi Universitas Kristen Duta Wacana yang telah mendanai penelitian ini.

2. Peserta didik, orang tua dan guru dari TK Ceria Yogyakarta, Sekolah (KB \&TK) Mata Air Yogyakarta, dan TK Indriyasana Jetis, Yogyakarta yang telah bersedia menjadi responden kami.

3. Klinik Tumbuh Kembang anak Rumah Sakit Umum Sardjito Yogyakarta yang telah bersedia berbagi pengetahuan mengenai anak usia prasekolah. 


\section{Pengembangan Aplikasi Permainan Edukasi Untuk Anak Prasekolh Menggunakan Pendekatan Child Centered Design.}

\section{Daftar Pustaka}

Adams, E., \& Rollings, A. (2007). Fundamentals of Game Design. New Jersey: Pearson Education, Inc.

Delima, R., Arianti, N.K., Pramudyawardani, B. (2015). Identifikasi Kebutuhan Pengguna untuk Aplikasi Permainan Edukasi Bagi Anak Usia 4 sampai 6 Tahun. Jurnal Teknik Informatika dan Sistem Informasi. Volume 1. Nomor 01. April 2015. Universitas Kristen Maranatha. Bandung

Handriyantini, E. (2009). Permainan Edukatif (Educational Games) Berbasis Komputer untuk Siswa Sekolah Dasar.

Hurd, D., \& Jenuings, E. (2009). Standardized Educational Games Ratings: Suggested Criteria.

Idler, S., 16 Agustus 2013, Child-Centered Design is User-Centered Design, But Then Different, diunduh dari http://uxkids.com/blog/child-centered-design-is-user-centered-design-but-then-different/

Markopoulos, P., Read, J., Hoysniemi, J., MacFarlane, S., 2008, Child Computer Interaction : Advances in Methodalogical Research, Cognitive, Technology and Work, Vol. 10 No. 2, page 79 - 81.

Nousiainen, T., 2008, Children's Involvement in the Design of Game-Based Learning Environments, Master Thesis, Department of Computer Science and Information Systems, University of Jyväskylä.

Pardo, S., Howard, S., Vetere, F. (2008). Child-Centred Evaluation : Broadening The Child/Designer Dyad, Research Article. Advances in Human-Computer Interaction, Vol. 2008.

Rubin, J., Chisnell, D., 2008, How To Plan, Design, And Conduct Effective Tests, Wiley Publishing Inc, Indianapolis, Indiana.

Ruterberg, M., 2003, User Centered Design : What, Why, and When, diunduh dari http://www.idemployee.id.tue.nl/g.w.m.rauterberg/publications/tekom03paper.pdf

The 1+1+1=1 website. (2013). [online] tersedia :

http://www.1plus1 plus1 equals1.net/2013/06/jack-and-the-beanstalk-printables/

Wallach, D., Scholz, S.C, 2012, User-Centered Design : Why and How to Put Users First in Software Development, diunduh dari www.springer.com/cda/content/.../cda.../9783642313707-c2.pdf 